\title{
Ductile cast irons: microstructure influence on fatigue crack propagation resistance
}

\author{
Francesco Iacoviello, Vittorio Di Cocco \\ Università di Cassino, Di.M.S.A.T., via G. Di Biasio 43, 03043 Cassino (FR), iacoviello@unicas.it
}

Mauro Cavallini

Università di Roma "Sapienza", DICMA, via Eudossiana 18, Roma

RIASSUNTO. In questo lavoro è analizzata l'influenza della microstruttura sulla resistenza alla propagazione della cricca di fatica in cinque differenti ghise sferoidali. Sono state considerate quattro ghise sferoidali caratterizzate da differenti frazioni volumetriche di ferrite e di perlite, effettuando prove di propagazione della cricca di fatica in accordo con la normativa ASTM E647 ( $\mathrm{R}$ pari a 01, 0.5 e 0.75 , rispettivamente). I risultati ottenuti sono stati quindi comparati con il comportamento di una ghisa sferoidale austemprata. I micromeccanismi di danneggiamento sono stati investigati utilizzando le seguenti procedure:

- Analisi delle superfici di frattura "tradizionale" effettuata mediante un microscopio elettronico a scansione (SEM);

- Ricostruzione quantitativa 3D delle superfici analizzate con il SEM;

- Analisi SEM dell'evoluzione del profilo longitudinale della cricca;

- Analisi al microscopio ottico (LOM) del profilo trasversale della cricca.

ABSTRACT. Microstructure influence on fatigue crack propagation resistance in five different ductile cast irons (DCI) was investigated. Four ferrite/pearlite volume fractions were considered, performing fatigue crack propagation tests according to ASTM E647 standard (R equals to 0.1, 0.5 and 0.75, respectively). Results were compared with an austempered DCI. Damaging micromechanisms were investigated according to the following procedures:

- "traditional" Scanning Electron Microscope (SEM) fracture surfaces analysis;

- SEM fracture surface analysis with 3D quantitative analysis;

- SEM longitudinal crack profile analysis

- Light Optical Microscope (LOM) transversal crack profile analysis;

KEYWORDS. Ductile irons; Microstructure; Fatigue crack propagation.

\section{INTRODUCTION}

$\mathrm{U}$ $\mathrm{p}$ to the first half of the last century, only malleable irons were able to partially offer a combination of grey iron castability and steel mechanical properties (first of all, toughness). These cast irons were obtained as a result of extended annealing treatment of white iron, with a matrix microstructure that was characterized by different ferrite and pearlite volume fractions, as a function of the cooling cycle. The main problems of this procedure were the high costs and the difficulty to cast sound white iron components. In 1943, in the International Nickel Company Research Laboratory, a magnesium addition allowed to obtain a cast iron containing not flakes but nearly perfect graphite spheres. In 1948, at the American Foundryman Society Convention, it was announced that a small amount of cerium allowed to obtain the same result $[1,2]$. 
After more than fifty years, ductile iron should be considered as a family of materials offering a wide range of properties depending on the chemical composition and heat treatment and the consequent microstructure modifications. Matrix microstructure importance is emphasized by the use of matrix names to commonly designate the different types of ductile irons (Fig. 1):

- Ferritic DCI: this DCI is characterized by a good ductility and impact resistance; ultimate tensile and yield strength are equivalent to a low carbon steel.

- Pearlitic DCI: a pearlitic DCI is characterized by high strenght, good wear resistance and reduced ductility and impact resistance.

- Ferritic-pearlitic DCIs: these are the most common DCI; properties are intermediate between ferritic and pearlitic grades (Fig. 2), and good machinability is obtained with low production costs.

- Austenitic DCI: this DCI shows a high corrosion and oxidation resistance, with good strength and dimensional stability at high temperature.

- Martensitic DCI: these DCI are obtained controlling both the chemical composition (to prevent pearlite formation) and the heat treatment (quench and temper): very high strength and wear resistance are obtained, but with lower values of ductility and toughness.

- Bainitic DCI: this DCI is obtained controlling chemical composition and/or heat treatment: the result is a hard and wear resistant material.

- Austempered DCI (also ADI): ADI are obtained after an austempering heat treatment, with very high tensile strength values (twice than a pearlitic DCI), high elongation and toughness.

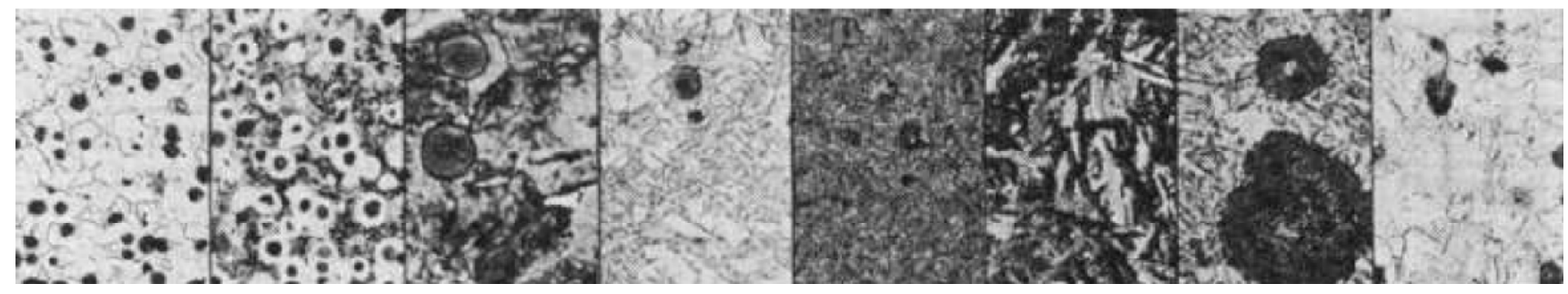

Figure 1: DCI microstructures (different magnifications). From left to right: ferritic, ferritic-pearlitic, pearlitic, martensitic, bainitic, tempered, austempered (UTS $=1050 \mathrm{MPa}$ ), austempered ( UTS =1600 MPa), austenitic [1].

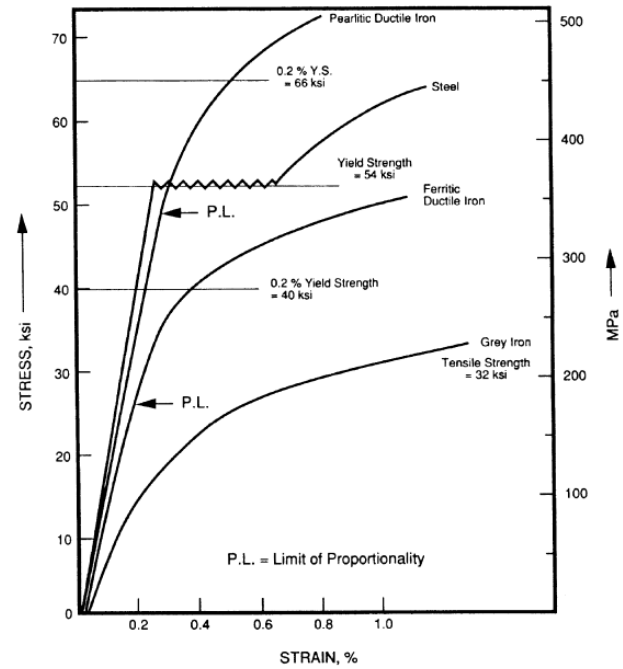

Figure 2: Elastic and yielding behavior for steel, gray iron and ferritic and pearlitic DCIs [1].

Focusing fatigue crack propagation resistance, references results show an evident influence of matrix microstructure, graphite elements morphology, size and volume fraction and chemical composition [3-10]. The aim of this work is the analysis of microstructure influence on fatigue crack propagation micromechanisms, considering different loading conditions (applied $\Delta \mathrm{K}$ and $\mathrm{R}$ ). Five different DCI were analyzed [11-21]: four DCI were characterized by a ferritic pearlitic matrix (different ferrite and pearlite volume fractions); the fifth investigated DCI was an austempered one. 


\section{INVESTIGATED DCIS AND EXPERIMENTAL PROCEDURES}

$\mathrm{I}$ nvestigated DCIs were characterized by five different matrix microstructures and by a good graphite elements nodulization. The first three ferritic-pearlitic DCIs were obtained by means of chemical composition control: as a results, matrix microstructures ranged from a completely ferritic DCI up to a completely pearlitic one. Chemical compositions and phases volume fractions are in Tab. 1-3.

\begin{tabular}{ccccccccc}
\hline $\mathrm{C}$ & $\mathrm{Si}$ & $\mathrm{Mn}$ & $\mathrm{S}$ & $\mathrm{P}$ & $\mathrm{Cu}$ & $\mathrm{Cr}$ & $\mathrm{Mg}$ & $\mathrm{Sn}$ \\
3.66 & 2.72 & 0.18 & 0.013 & 0.021 & 0.022 & 0.028 & 0.043 & 0.010 \\
\hline
\end{tabular}

Table 1: DCI EN GJS350-22 chemical composition (100\% ferrite), Fig. 3.

\begin{tabular}{cccccccccc}
\hline $\mathrm{C}$ & $\mathrm{Si}$ & $\mathrm{Mn}$ & $\mathrm{S}$ & $\mathrm{P}$ & $\mathrm{Cu}$ & $\mathrm{Cr}$ & $\mathrm{Mg}$ & $\mathrm{Sn}$ \\
3.65 & 2.72 & 0.18 & 0.010 & 0.03 & - & 0.05 & 0.055 & 0.035 \\
\hline
\end{tabular}

Table 2: DCI EN GJS500-7 chemical composition (50\% ferrite - 50\% pearlite), Fig. 4.

\begin{tabular}{cccccccccccc}
\hline $\mathrm{C}$ & $\mathrm{Si}$ & $\mathrm{Mn}$ & $\mathrm{S}$ & $\mathrm{P}$ & $\mathrm{Cu}$ & $\mathrm{Mo}$ & $\mathrm{Ni}$ & $\mathrm{Cr}$ & $\mathrm{Mg}$ & $\mathrm{Sn}$ \\
3.59 & 2.65 & 0.19 & 0.012 & 0.028 & 0.04 & 0.004 & 0.029 & 0.061 & 0.060 & 0.098 \\
\hline
\end{tabular}

Table 3: DCI EN GJS700-2 chemical composition (100\% pearlite), Fig. 5.

Ferritic-pearlitic DCI obtained by means of a chemical composition control (Tab.2) is characterized by the presence of ferritic shields around graphite nodules embedded in a pearlitic matrix (Fig.4).

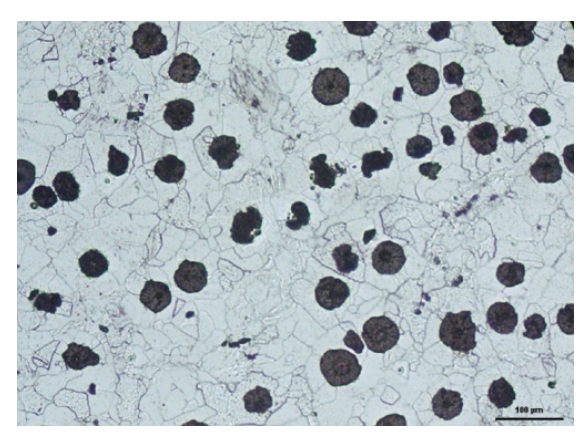

Figure 3: DCI EN GJS350-22 microstructure $(100 \%$ ferrite).

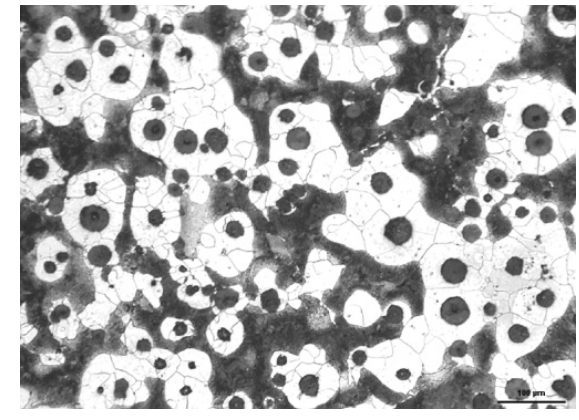

Figure 4: DCI EN GJS500-7 microstructure $(50 \%$ ferrite $-50 \%$ pearlite)

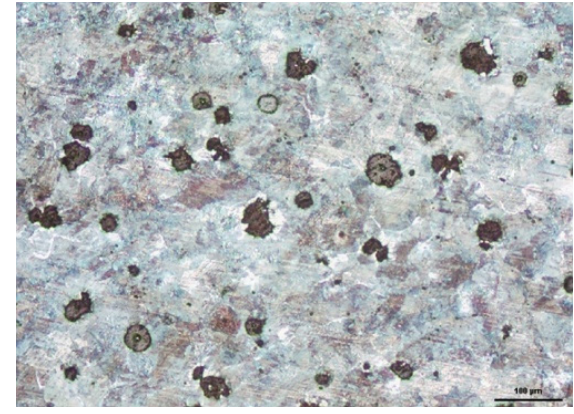

Figure 5: DCI EN GJS700-2 microstructure $(100 \%$ pearlite).

The annealing of a pearlitic DCI EN GJS700-2 (Tab. 3) allowed to obtain a fourth ferritic-pearlitic DCI, with ferrite and pearlite volume fraction equal to about $50 \%$. This ferritic pearlitic DCI obtained by means of heat treatment control is characterized by a microstructure that does not show ferritic shields around graphite nodules (Fig. 6), as in EN GJS500-7. However, graphite elements nodularity is always high.

The fifth investigate DCI is an austempered one (ADI, GGG 70BA; chemical composition in Tab. 4). In order to obtain an ADI, the following heat treatment was performed:

$\checkmark \quad 910^{\circ} \mathrm{C}(70 \mathrm{~min}$.$) ;$

$\checkmark$ Salt bath cooling (2 hours at $370^{\circ} \mathrm{C}$ and, after, 60 sec. at $320^{\circ} \mathrm{C}$ );

$\checkmark$ Air cooling up to room temperature.

After this heat treatment, a reduced graphite nodules degeneration was observed and a bainitic microstructure was obtained, with a really low residual ferrite volume fraction.

\begin{tabular}{ccccccc}
\hline $\mathrm{C}$ & $\mathrm{Si}$ & $\mathrm{Mn}$ & $\mathrm{Mo}$ & $\mathrm{Ni}$ & $\mathrm{Sn}$ & $\mathrm{S}$ \\
3.61 & 2.23 & 0.32 & 0.42 & 0.52 & 0.045 & 0.015 \\
\hline
\end{tabular}

Table 4: Austempered DCI chemical composition GGG 70BA, Fig. 7. 


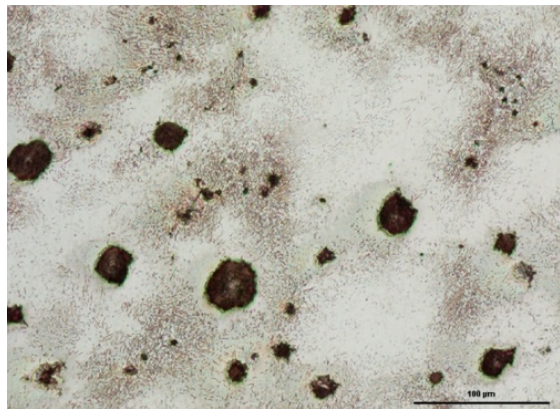

Figure 6: Ferritic-pearlitic DCI (obtained by means of a pearlitic DCI annealing). $50 \%$ ferrite $-50 \%$ pearlite.

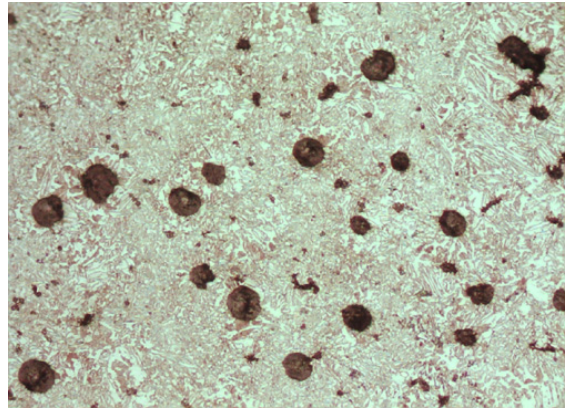

Figure 7: Austempered DCI GGG 70BA

(ADI).

Fatigue crack propagation tests were performed in laboratory conditions according to ASTM E647 standard [22], using 10 $\mathrm{mm}$ thick CT (Compact Type) specimens and considering three different stress ratio values (e.g. $\mathrm{R}=\mathrm{P}_{\min } / \mathrm{P}_{\max }=0.1 ; 0.5$; 0.75). Tests were performed using a computer controlled servohydraulic machine in constant load amplitude conditions, considering a $20 \mathrm{~Hz}$ loading frequency, a sinusoidal loading waveform. Crack length measurements were performed by means of a compliance method using a double cantilever mouth gage and controlled using an optical microscope (x40). In order to investigate the fatigue crack propagation micromechanisms, different procedures were applied:

- Scanning electron microscope (SEM) observations of the crack path during fatigue crack propagation test (cracks propagate from left to right);

- "Traditional” SEM fracture surface analysis (cracks propagate from left to right);

- 3D fracture surface reconstruction performed after SEM analysis;

- $\quad$ Light optical microscope (LOM) transversal crack paths analysis.

These experimental procedures were not applied to all the investigated DCI.

3D fracture surface reconstruction procedure was performed in order to perform a quantitative analysis of the microstructure influence on the graphite elements debonding morphology [14].

Corresponding to the same specimen position, a stereoscopic image was obtained performing an eucentric tilting around the vertical axis and capturing two different images (Fig. 8), with a tilting angle equal to $5^{\circ}$. A $3 \mathrm{D}$ surface reconstruction was performed by means of Alicona MeX software, obtaining images as in Fig. 9. 3D quantitative reconstruction allowed to investigate fracture surface profiles, as reported in Fig. 10.
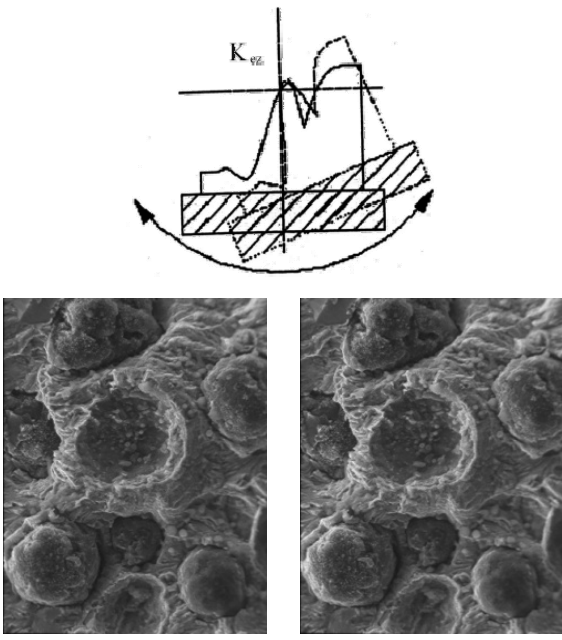

Figure 8: Two SEM images obtained by means of an eucentric tilting around the vertical.

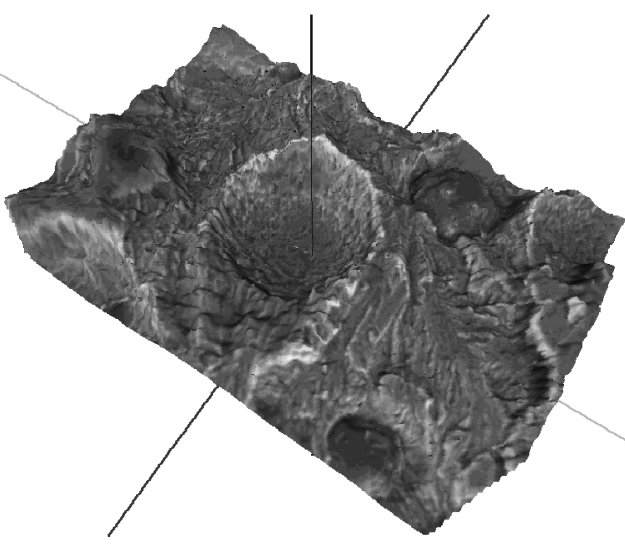

Figure 9: 3D reconstructed fracture surface (50\% ferrite $-50 \%$ pearlite).

At least 50 voids were considered for all the investigated ductile irons and fracture surface profiles were quantitatively analyzed. Each void was characterized considering an approximation sphere (the "lost" graphite nodule) and three different geometrical parameters were considered: 
- Void depth "K" $[\mu \mathrm{m}]$;

- Void diameter "L" $[\mu \mathrm{m}]$;

- Approximation sphere diameter " $\mathrm{D}$ " $[\mu \mathrm{m}]$

Relations among these geometric parameters depend on debonding process. If graphite elements debonding is completely fragile, it follows that $\mathrm{K} \leq \mathrm{D} / 2$ and $\mathrm{L} \leq \mathrm{D} / 2$. On the other side, a ductile debonding process implies $\mathrm{K}>\mathrm{D} / 2$ and $\mathrm{L}>$ $\mathrm{D} / 2$, with differences that increase with the importance of ductile damage mechanism.

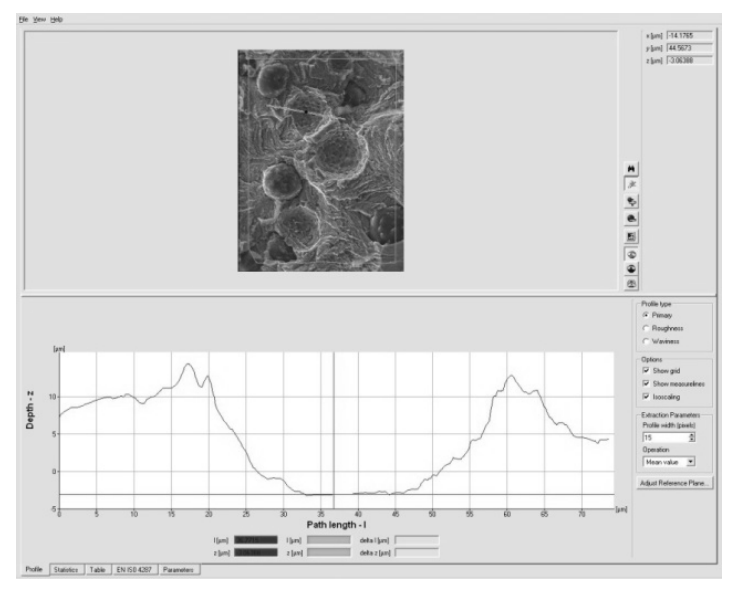

Figure 10: Fracture surface profile quantitative analysis.

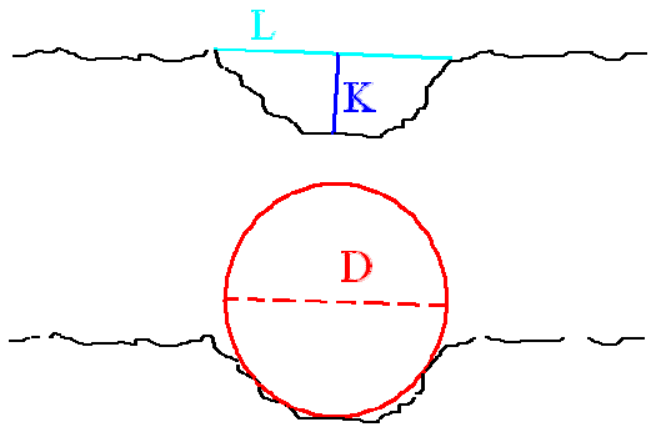

Figure 11: Geometrical parameters used in the surface profile analysis.

Light optical microscope (LOM) transversal crack paths analysis was performed according to the following procedure [Fig. 12]:

- Fracture surface nickel coating (in order to protect fracture surface during cutting).

- Fractured specimen transversal cutting, by means of a diamond saw.

- Metallographic preparation of the section (up to $0.2 \mu \mathrm{m} \mathrm{Al}_{2} \mathrm{O}_{3}$ powder).

- Nital 4 chemical etching (5 s).

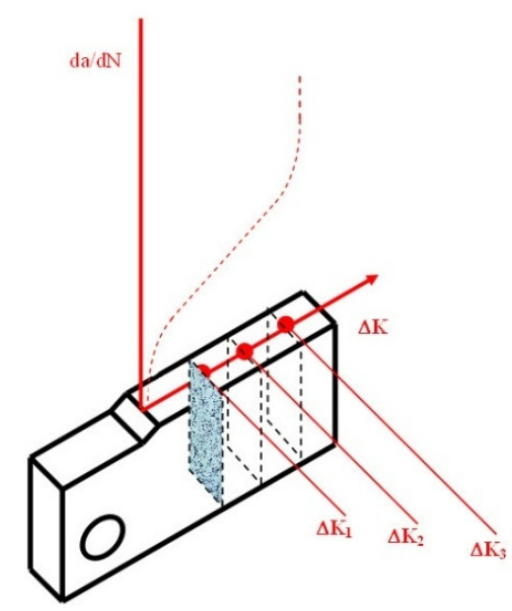

Figure 12: Light optical microscope (LOM) transversal crack paths analysis.

\section{RESULTS AND COMMENTS}

$\mathrm{F}$

ig. 13 and 14 show stress ratio (R) and microstructure influence on fatigue crack propagation resistance. Stress ratio influence in ferritic-pearlitic DCI obtained by means of chemical composition control is shown in Fig. 13. Fig. 14 compares the behaviour of the DCI obtained by means of heat treatment control with the ferritic-pearlitic DCI obtained controlling the chemical composition. 


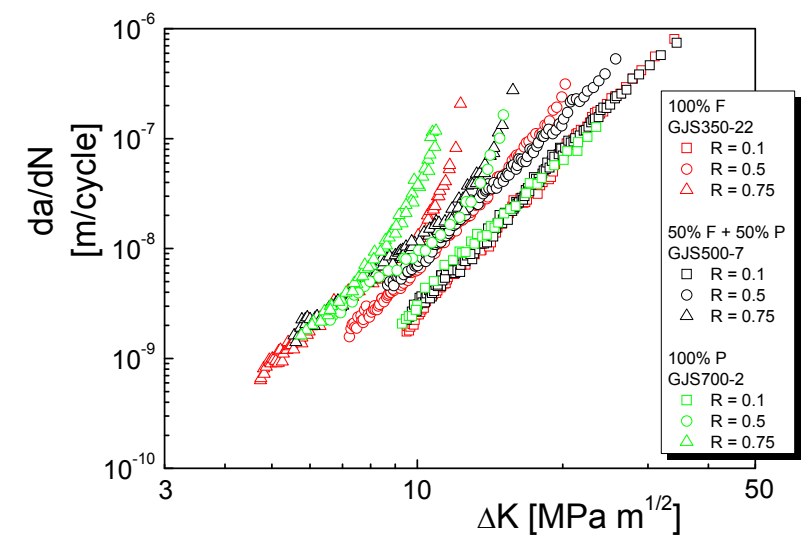

Figure 13: Stress ratio and microstructure influence on fatigue crack propagation resistance of ferritic-pearlitic DCI (obtained controlling the chemical composition).

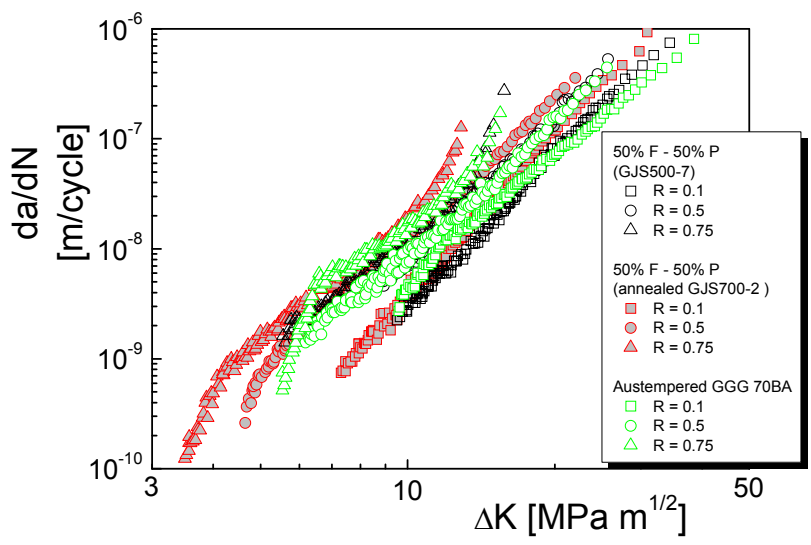

Figure 14: DCI fatigue crack propagation resistance in ferriticpearlitic and austempered DCIs.

For all the investigated ductile cast irons, fatigue crack growth rates $\mathrm{da} / \mathrm{dN}$ increases with the stress ratio, for the same $\Delta \mathrm{K}$ values. This behaviour is due to crack closure effect that can be crack tip plasticity, oxide forming and/or fracture surface roughness induced $[23,24]$. Roughness surface analysis and scanning electron microscope (SEM) fracture surface investigation $[11,13]$ show a low influence of the oxide forming and fracture surface roughness induced crack closure effect. Considering lower $\mathrm{R}$ values (e.g. $\mathrm{R}=0.1$ ) or lower $\Delta \mathrm{K}$ values (near threshold), fatigue crack propagation is not influenced by matrix microstructure. Focusing ferritic-pearlitic DCIs obtained controlling the chemical composition, the best behavior is shown by GJS500-7 (50\% ferrite - 50\% perlite): for the same loading conditions, this DCI is characterized by lower crack growth rate values, especially for higher $\Delta \mathrm{K}$ and/or $\mathrm{R}$ values (Fig. 13).

Comparing GJS500-7 with the ferritic-pearlitic DCI obtained annealing the pearlitic DCI, the different phases distribution implies differences in fatigue crack propagation resistance. GJS500-7 fatigue crack propagation resistance is higher than the ferritic-pearlitic DCI obtained annealing the pearlitic DCI, and is analogous to the resistance offered by the austempered DCI, for all the investigated loading conditions.

\section{SEM crack profile analysis}

Considering ferritic DCI, ferritic matrix-graphite nodules interfaces are not necessary a preferential propagation path: in fact, crack could propagate both nearby graphite nodules (Fig. 15) corresponding to the matrix-nodules interface (Fig. 16 and 17). However, the consequent debonding is characterized by the presence of residual graphite on ferritic fracture surface (Fig. 17). Some secondary cracks are also observed: they could initiate both at matrix-nodules interfaces (Fig. 18) and in ferritic matrix (Fig. 19, 20). These secondary cracks are characterized by a really reduced propagation path $(100-$ $200 \mu \mathrm{m}$ max.). Graphite nodules are also characterized by the presence of a "secondary damage", as really short secondary cracks inside Nearby of the cracks, graphite nodules do not show any secondary damage, neither as cracks inside nodule or as cracks at nodules-matrix interface.

Focusing fully pearlitic DCI, fatigue crack - graphite nodules interactions could imply both a nodule disgregation (Fig. 21) and (more frequently) a pearlitic matrix - nodules "clear" debonding, withoud residual graphite on pearlitic fracture surface (Fig. 22, 23).

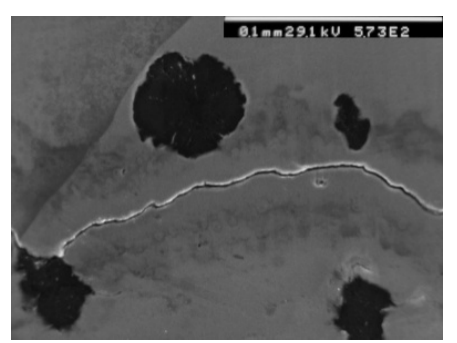

Figure 15: Ferritic DCI $(\mathrm{R}=0.1, \Delta \mathrm{K}=10 \mathrm{MPa} \sqrt{\mathrm{m}})$.

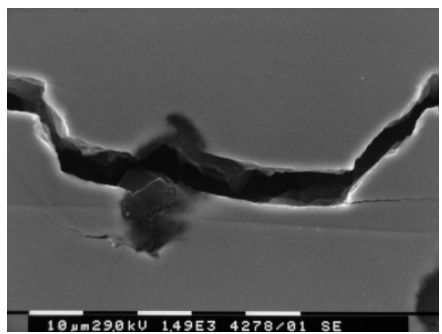

Figure 16: Ferritic DCI $\left(\mathrm{R}=0.5, \Delta \mathrm{K}=10 \mathrm{MPa} \sqrt{\mathrm{m}}_{\mathrm{m}}\right.$.

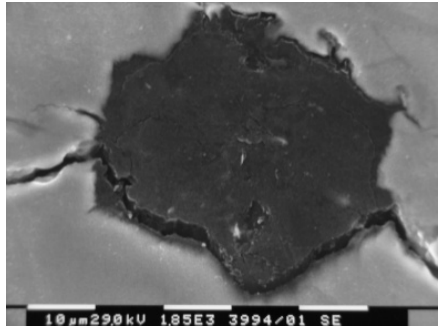

Figure 17: Ferritic DCI $\left(\mathrm{R}=0.5, \Delta \mathrm{K}=12 \mathrm{MPa} \sqrt{\mathrm{m}}_{\text {). }}\right.$.

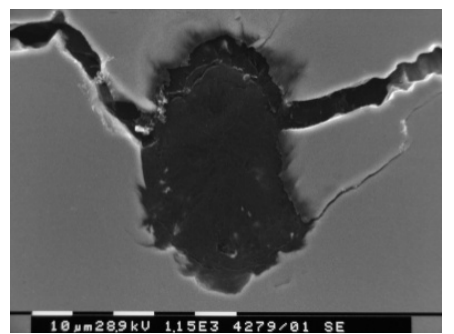

Figure 18: Ferritic DCI $\left(\mathrm{R}=0.75, \Delta \mathrm{K}=9 \mathrm{MPa} \sqrt{\mathrm{m}}_{\text {). }}\right.$ 
Ferrite and cementite lamellae are not necessarly a preferential propagation path for the fatigue crack (Fig. 24, 25, 26), also if pearlite lamellae and crack path are almost paralel. Secondary cracks are less frequent if compared to ferritic DCI (Fig. 27 ), with a really reduced path. Nearby the fatigue crack, graphite nodules are characterized by the presence of secondary crack inside the nodule (Fig. 28).

Ferritic-pearlitic DCI GJS500-7 crack paths are characterized by the presence of many secondary cracks that initiate from the main fatigue crack path (as in the ferritic DCI, Fig. 29) and by the presence of a "clean" graphite elements - matrix debonding (as in the pearlitic DCI, Fig 30, 31, 32).

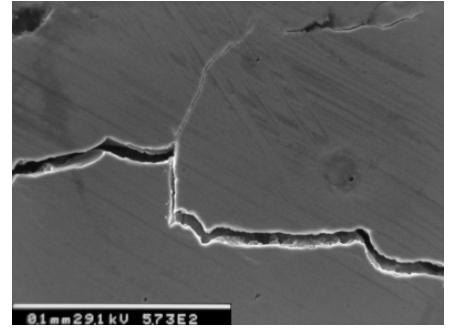

Figure 19: Ferritic DCI $(\mathrm{R}=0.5, \Delta \mathrm{K}=13 \mathrm{MPa} \sqrt{\mathrm{m}})$.

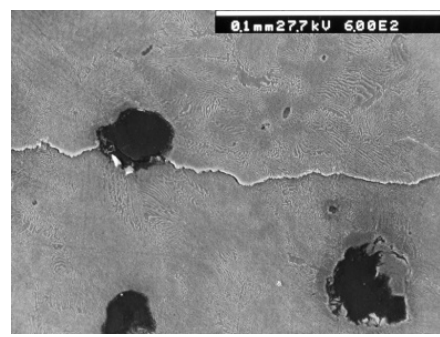

Figure 21: Pearlitic DCI $(\mathrm{R}=0.1, \Delta \mathrm{K}=13 \mathrm{MPa} \sqrt{\mathrm{m}})$.

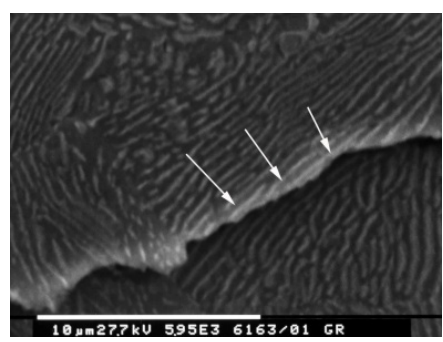

Figure 25: Pearlitic DCI $(\mathrm{R}=0.1, \Delta \mathrm{K}=12 \mathrm{MPa} \sqrt{\mathrm{m}})$.

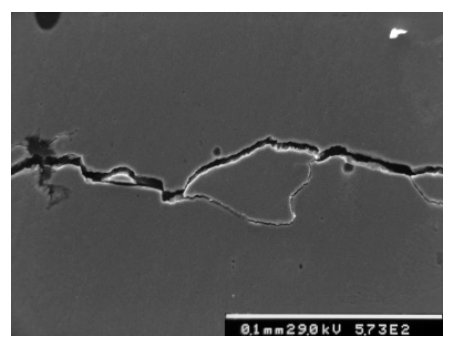

Figure 29: Ferritic-pearlitic DCI GJS500-7

$(\mathrm{R}=0.75, \Delta \mathrm{K}=6 \mathrm{MPa} \sqrt{\mathrm{m}})$.

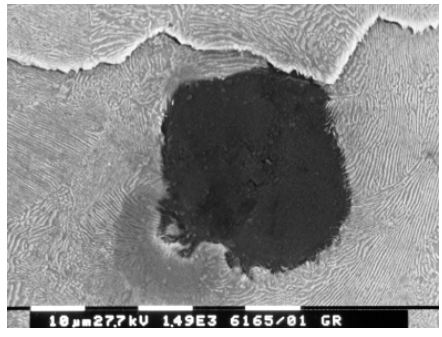

Figure 22: Pearlitic DCI $\left(\mathrm{R}=0.1, \Delta \mathrm{K}=15 \mathrm{MPa} \sqrt{\mathrm{m}}_{\text {). }}\right.$

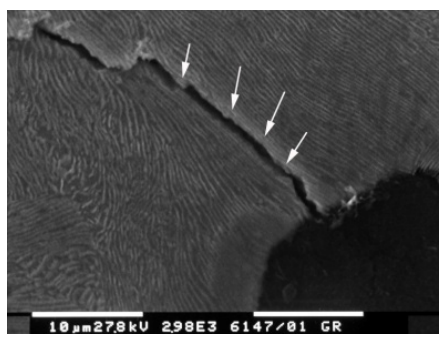

Figure 26: Pearlitic DCI $\left(\mathrm{R}=0.75, \Delta \mathrm{K}=8 \mathrm{MPa} \sqrt{\mathrm{m}}_{\text {). }}\right.$

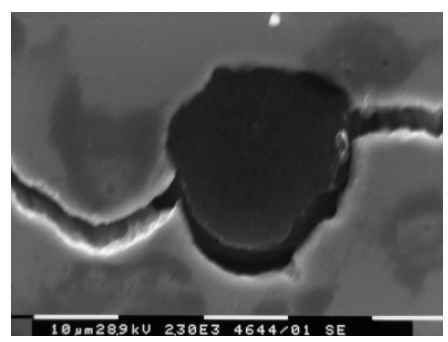

Figure 30: Ferritic-pearlitic DCI GJS500-7

$(\mathrm{R}=0.1, \Delta \mathrm{K}=10 \mathrm{MPa} \sqrt{\mathrm{m}})$.

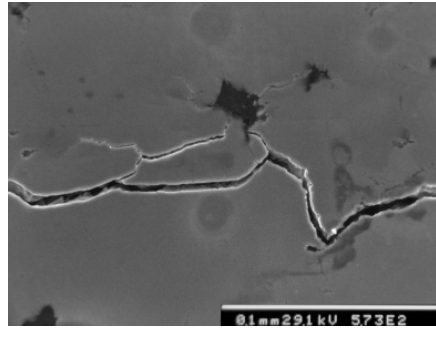

Figure 20: Ferritic DCI $(\mathrm{R}=0.5, \Delta \mathrm{K}=18 \mathrm{MPa} \sqrt{\mathrm{m}})$.

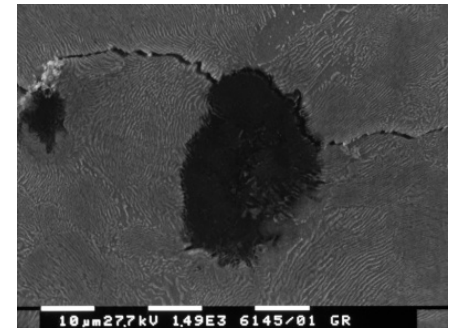

Figure 23: Pearlitic DCI $\left(\mathrm{R}=0.5, \Delta \mathrm{K}=10 \mathrm{MPa} \sqrt{\mathrm{m}}_{\text {). }}\right.$

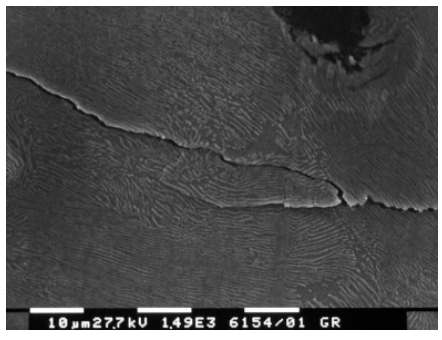

Figure 27: Pearlitic DCI $\left(\mathrm{R}=0.1, \Delta \mathrm{K}=11.5 \mathrm{MPa} \sqrt{\mathrm{m}}_{\mathrm{m}}\right.$.

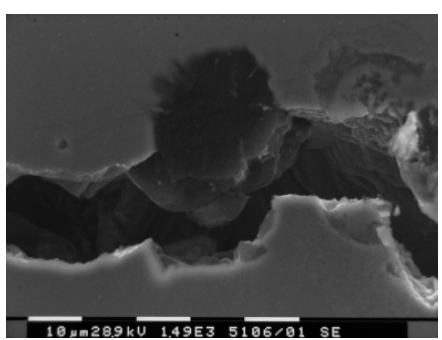

Figure 31: Ferritic-pearlitic DCI GJS500-7

$\left(\mathrm{R}=0.5, \Delta \mathrm{K}=8 \mathrm{MPa} \sqrt{\mathrm{m}}_{\mathrm{m}}\right.$.

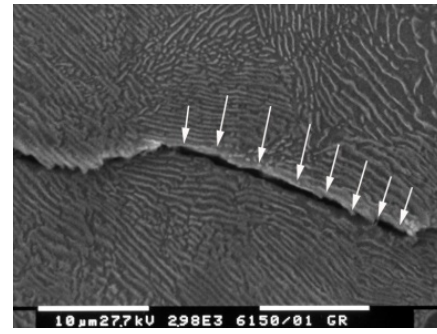

Figure 24: Pearlitic DCI $(\mathrm{R}=0.75, \Delta \mathrm{K}=7 \mathrm{MPa} \sqrt{\mathrm{m}})$.

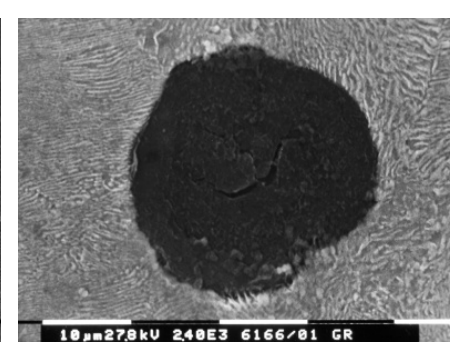

Figure 28: Pearlitic DCI (about $30 \mu \mathrm{m}$ from the crack).

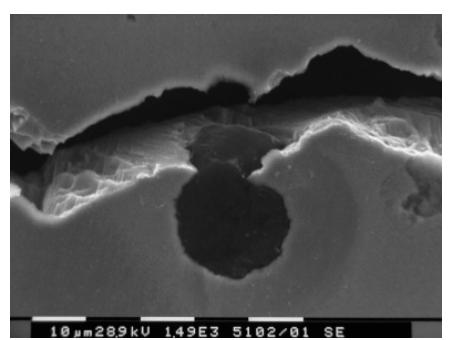

Figure 32: Ferritic-pearlitic DCI GJS500-7

$(\mathrm{R}=0.75, \Delta \mathrm{K}=8 \mathrm{MPa} \sqrt{\mathrm{m}})$. 


\section{SEM fracture surface analisys}

Ferritic DCI fracture surface is characterized by the presence of secondary cracks (Fig. 33) with some cleavage of ferritic grains (Fig. 34). Graphite nodules on fracture surface are partially disintegrated (Fig. 34), with evident residual graphite in cavities. (Fig. 35). Partial disintegration is confirmed both by the presence of damaged nodules (Fig. 36, point 1 and Fig. 37) and by the presence of residual graphite (Fig. 36, point 2). All the observed fracture morphologies are not influenced by the loading conditions ( $\mathrm{R}$ and/or $\Delta \mathrm{K}$ values).

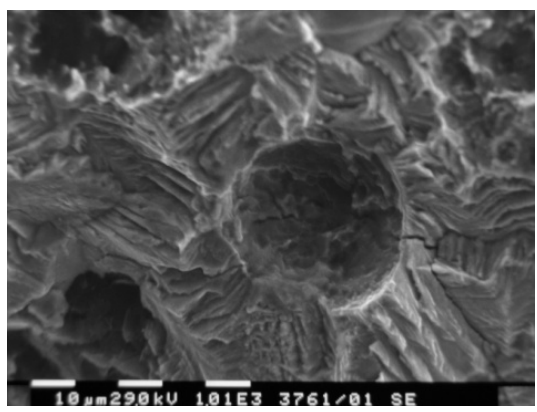

Figure 33: Ferritic DCI $\left(\mathrm{R}=0.1, \Delta \mathrm{K}=10 \mathrm{MPa} \sqrt{\mathrm{m}}_{\text {). }}\right.$.

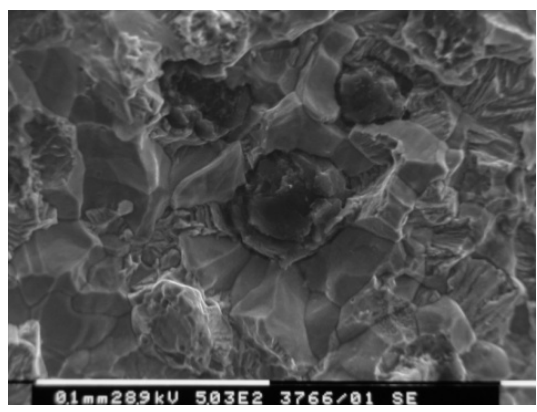

Figure 34: Ferritic DCI

$(\mathrm{R}=0.1, \Delta \mathrm{K}=12 \mathrm{MPa} \sqrt{\mathrm{m}})$.

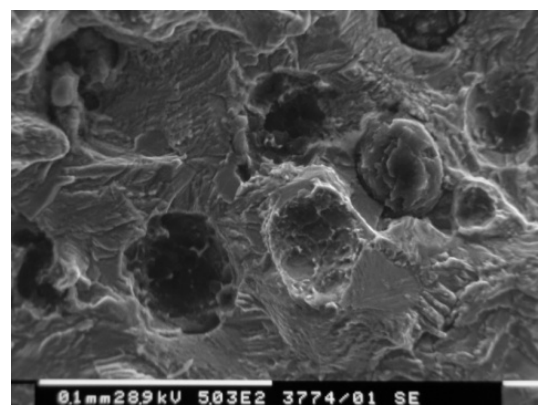

Figure 35: Ferritic DCI

$(\mathrm{R}=0.1, \Delta \mathrm{K}=19 \mathrm{MPa} \sqrt{\mathrm{m}})$.

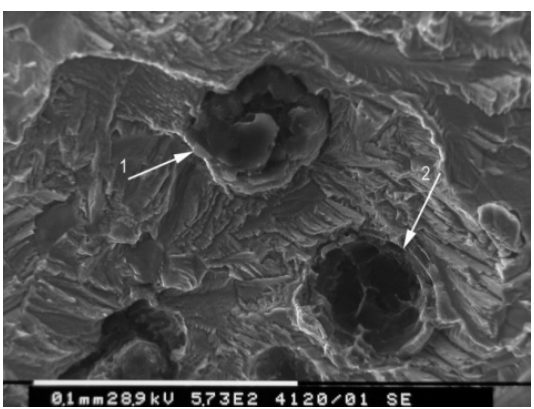

Figure 36: Ferritic DCI

$\left(\mathrm{R}=0.5, \Delta \mathrm{K}=9 \mathrm{MPa} \sqrt{\mathrm{m}}_{)}\right.$.

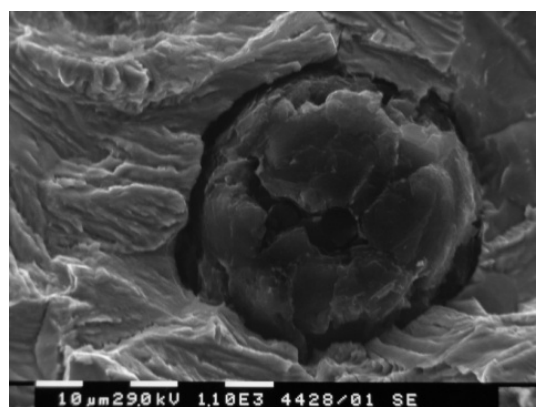

Figure 37: Ferritic DCI

$(\mathrm{R}=0.75, \Delta \mathrm{K}=11 \mathrm{MPa} \sqrt{\mathrm{m}})$.

Few secondary cracks are observed in pearlitic DCI and their length is really reduced (e.g., Fig. 38). Also cleavage importance is really reduced (Fig. 39, white arrow): striations are the main observed fatigue crack propagation micromechanisms (figure Fig. 39 and 40). The definition of this morphology as "striations" is not absolutely correct: in fact, considering the results obtained in crack profile analysis, the observed morphology is due to the fracture of pearlite lamellae during the fatigue crack propagation. Also rare "cleavage" is due to pearlite lamellae delamination and not to an effective cleavage mechanism (compare Fig. 24 with Fig 39). Focusing graphite nodules debonding, neither residual graphite nor graphite nodules disintegration are observed.

Considering the ferritic-pearlitic DCI GJS500-7, fracture surfaces are characterized by the presence of an evident cleavage in ferritic shields around the graphite nodules (Fig. 41, 42, 43). Analogously to the ferritic DCI, graphite nodules are characterized by a partial disintegration, with residual graphite in cavities; analogously to the pearlitic DCI, secondary cracks are almost absent. Also for this DCI, "striations" are manly connected to a delamination mechanism of pearlite lamellae.

Focusing the ferritic-pearlitic DCI obtained by means of an annealing of a pearlitic DCI, and considering the different distribution of ferritic grains and pearlitic colonies if compared to GJS500-7, cleavage around graphite nodule is absent, with graphite nodules that could be both partially disintegrated (Fig. 44) and absolutely sound (Fig. 45, 46). No residual graphite in cavities is observed.

Also ADI fracture surface, with its bainitic microstructure, is characterized by the presence of delamination (Fig. 47). Graphite nodules could be sometimes partially disintegrated (Fig. 47), but an absolutely sound shape is more frequent (Fig. 48, 49), with an evident ductile and "clean" matrix-nodules debonding. Secondary cracks are absent or really short. 


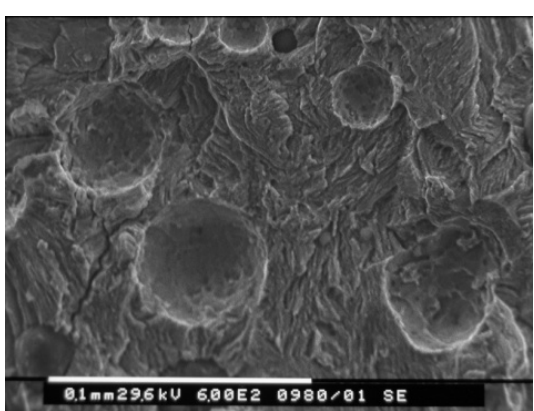

Figure 38: Pearlitic DCI

$\left(\mathrm{R}=0.5, \Delta \mathrm{K}=10 \mathrm{MPa} \sqrt{\mathrm{m}}_{\text {). }}\right.$.

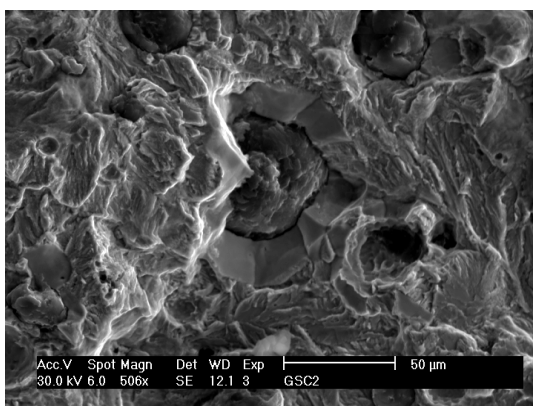

Figure 41: Ferritic-pearlitic DCI $\left(\mathrm{R}=0.1, \Delta \mathrm{K}=15 \mathrm{MPa} \sqrt{\mathrm{m}}_{\text {). }}\right.$

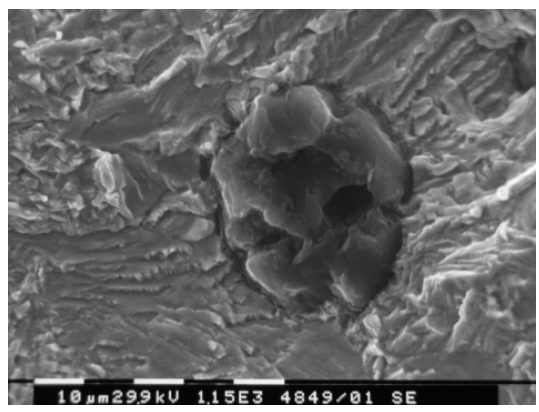

Figure 44: Ferritic-pearlitic DCI (annealed pearlitic DCI)

$\left(\mathrm{R}=0.5, \Delta \mathrm{K}=6 \mathrm{MPa} \sqrt{\mathrm{m}}_{\text {) }}\right.$.

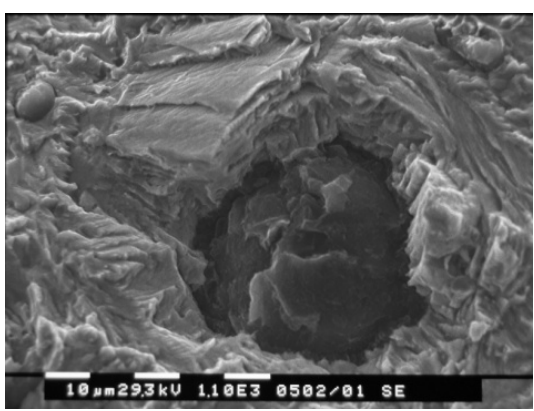

Figura 47: Austempered DCI $(\mathrm{R}=0.5, \Delta \mathrm{K}=12 \mathrm{MPa} \sqrt{\mathrm{m}})$.

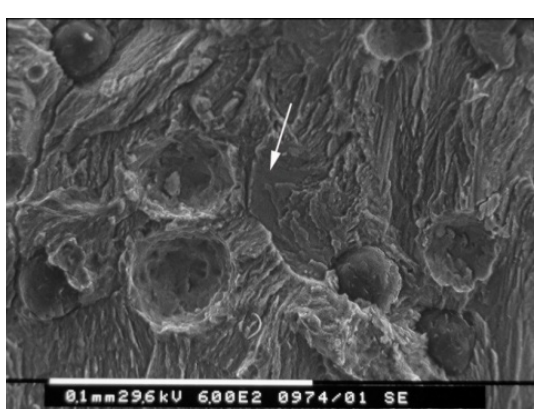

Figure 39: Pearlitic DCI

$\left(\mathrm{R}=0.75, \Delta \mathrm{K}=8 \mathrm{MPa} \sqrt{m}_{\mathrm{m}}\right.$.

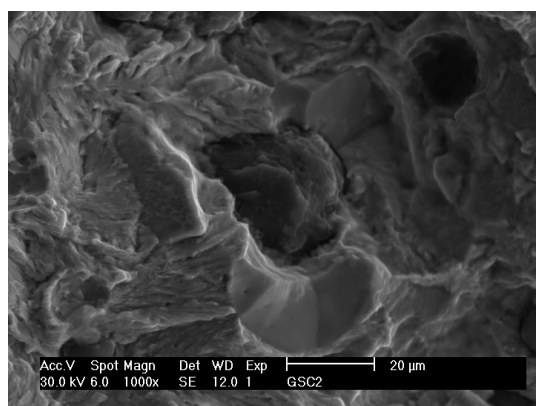

Figure 42: Ferritic-pearlitic DCI $\left(\mathrm{R}=0.1, \Delta \mathrm{K}=18 \mathrm{MPa} \sqrt{\mathrm{m}}_{\text {). }}\right.$

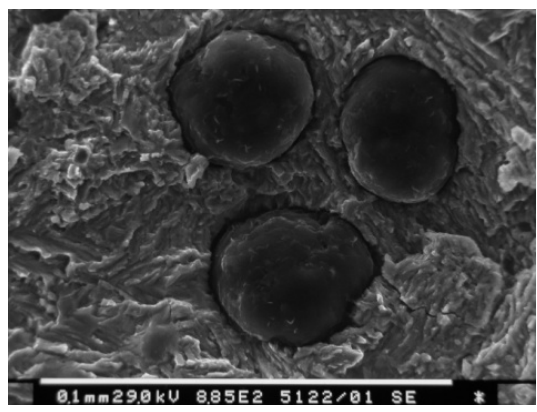

Figura 45: Ferritic-pearlitic DCI (annealed pearlitic DCI)

$(\mathrm{R}=0.75, \Delta \mathrm{K}=7 \mathrm{MPa} \sqrt{\mathrm{m}})$.

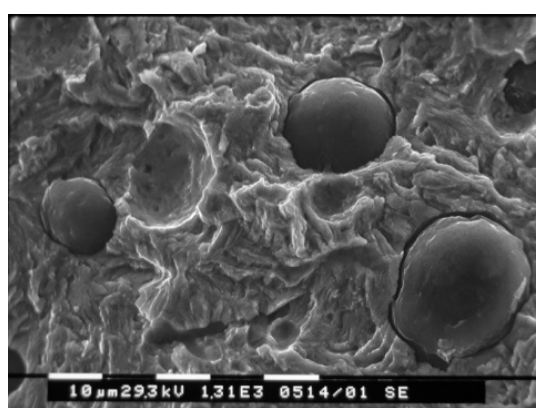

Figura 48: Austempered DCI $\left(\mathrm{R}=0.1, \Delta \mathrm{K}=6 \mathrm{MPa} \bigvee_{\mathrm{m}}\right)$.

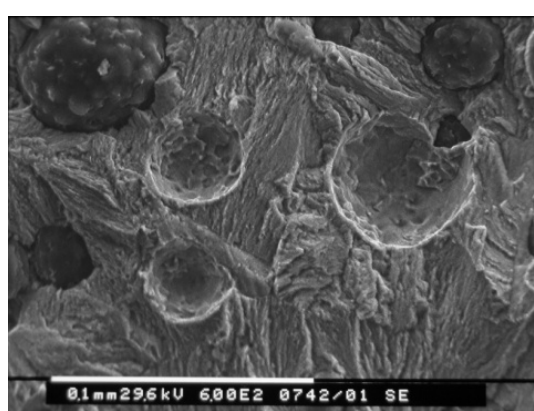

Figure 40: Pearlitic DCI

$(\mathrm{R}=0.1, \Delta \mathrm{K}=16 \mathrm{MPa} \sqrt{\mathrm{m}})$.

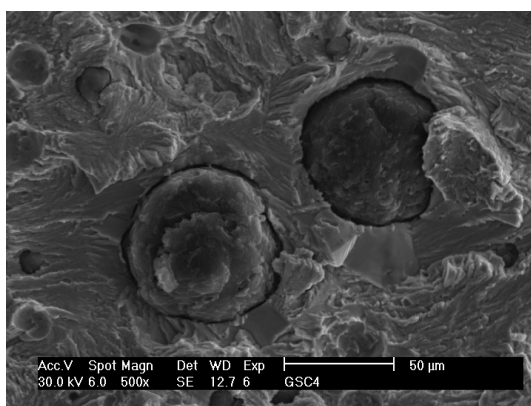

Figure 43: Ferritic-pearlitic DCI $\left(\mathrm{R}=0.75, \Delta \mathrm{K}=8 \mathrm{MPa} \sqrt{\mathrm{m}}_{\text {). }}\right.$.

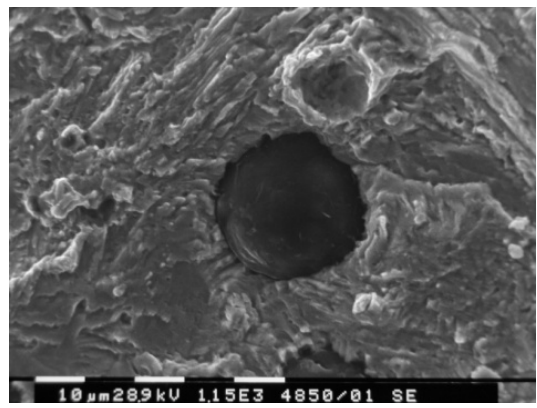

Figura 46: Ferritic-pearlitic DCI (annealed pearlitic DCI) $(\mathrm{R}=0.1, \Delta \mathrm{K}=12 \mathrm{MPa} \sqrt{\mathrm{m}})$.

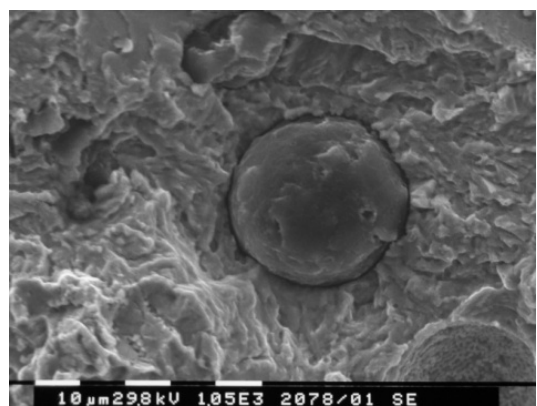

Figura 49: Austempered DCI $\left(\mathrm{R}=0.1, \Delta \mathrm{K}=18 \mathrm{MPa} \sqrt{\mathrm{m}}_{\mathrm{m}}\right.$. 


\section{$3 D$ fracture surface analysis}

The aim of this experimental procedure was to analyze the microstructure influence on graphite nodules - matrix debonding and to quantify a ductile component in this damaging mechanism (Fig. 50, 51).

Almost all the investigated voids are characterized by " $\mathrm{L}>\mathrm{D}$ ", for all the investigated microstructures. It implies that a ductile component in the debonding mechanism is always present. Microstructure strongly affects the experimental results distribution. Pearlitic DCI is characterized by the lowest differences "L - D" (completely fragile debonding corresponds to " $\mathrm{L}-\mathrm{D}=0$ "), and fully ferritic DCI is characterized by the higher "L-D" values (higher ductile deformation during debonding).

Ferritic-pearlitic DCI shows intermediate "L-D" values. This is probably due to the different mechanical behaviour of ferritic shields and pearlitic matrix that induces a compression stress state in ferritic shields corresponding to $K_{\min }$, and a consequent reduced ductile debonding.

ADI is characterized by "L-D" experimental results distribution that is similar to ferritic-pearlitic DCI and probably crack closure mechanisms are the same as in ferritic-pearlitic DCI, due to the presence of residual ferrite around graphite elements. Differences in the mechanical behaviour of pearlite and bainite are not so relevant. In fact, ferritic-pearlitic and austempered DCI crack growth rates are comparable for all the investigated experimental conditions (Fig. 14).

Also the analysis of voids depths " $\mathrm{K}$ " as a function of the approximation sphere diameters " $\mathrm{D}$ " allows to obtain an analogous classification of the importance of the ductile deformation in the debonding mechanism, with the fully pearlitic microstructure that is characterized by " $\mathrm{K} \leq \mathrm{D} / 2$ " (completely fragile spheroids debonding) and other investigated microstructures that are characterized by a higher importance of the ductile deformation in the debonding mechanism, with a consequent higher scatter of the experimental results.

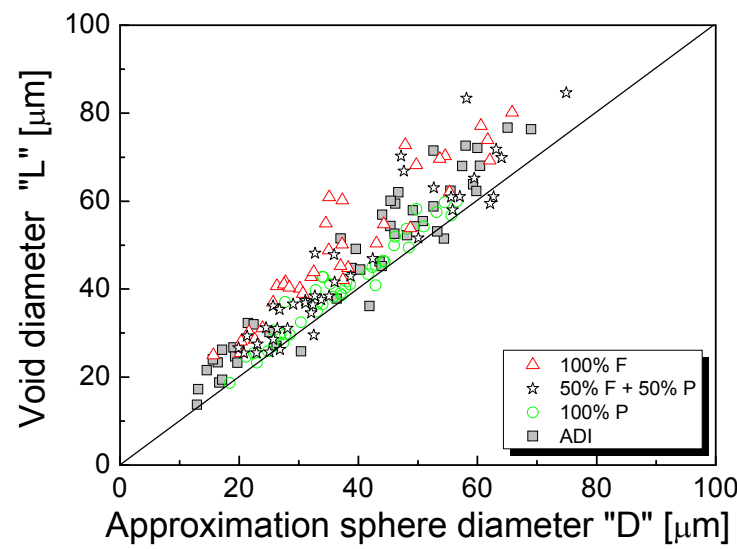

Figure 50: Four investigated ductile irons. Approximation sphere diameter - void diameter.

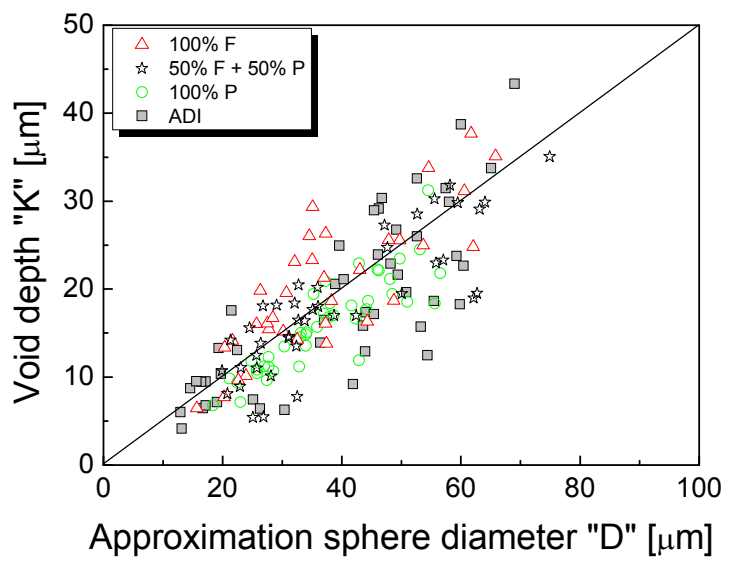

Figure 51: Four investigated ductile irons. Approximation sphere diameter - void depth.

\section{LOM transversal crack paths analysis}

Considering ferritic DCI, LOM transversal crack path analysis confirms graphite nodules disintegration as an important damaging mechanism (Fig. 52 and 53), and the presence of residual graphite inside cavities is also evident (Fig. 54).

Pearlitic DCI is characterized by an absolutely fragile debonding, without graphite element disintegration and without residual graphite inside cavities (Fig. 55, 56 and 57). Considering both ferritic and pearlitic DCI, the observations concerning the ductile or fragile debonding do not depend on the loading conditions ( $\mathrm{R}$ and applied $\Delta \mathrm{K}$ ).

Ferritic-pearlitic GJS500-7 DCI crack profile is characterized by the presence of partially disintegrated and sound graphite nodules, whith residual graphite that could be present inside cavities (Fig. 58, 59 and 60). The interface between pearlitic matrix and ferritic shields seems to act as a preferential crack propagation path (Fig. 59), together with the graphite nodules - ferritic shields interfaces.

Considering the ferritic-pearlitic DCI obtained annealing a pearlitic DCI, it is possible to observe a higher density of partially disintegrated graphite nodules, if compared to ferritic-pearlitic GJS500-7 DCI (Fig. 61). However, many sound graphite nodules are always present and their debonding from matrix does not show an evident plastic deformation of the matrix. 


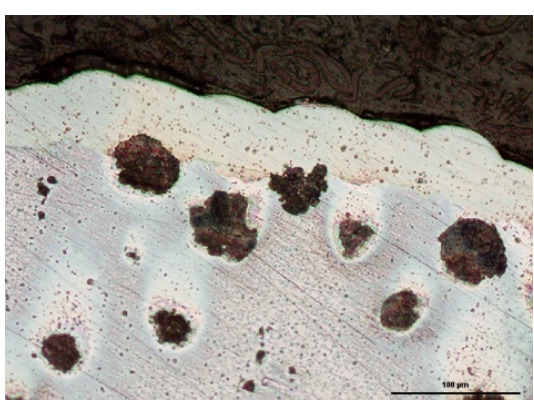

Figure 52: Ferritic DCI $(\mathrm{R}=0.1, \Delta \mathrm{K}=15 \mathrm{MPa} \sqrt{\mathrm{m}}$.

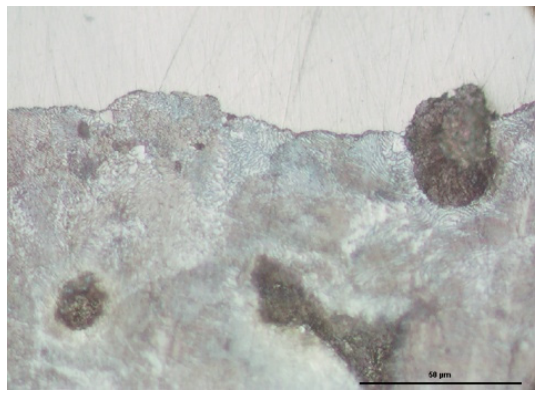

Figure 55: Pearlitic DCI

$\left(\mathrm{R}=0.1, \Delta \mathrm{K}=10 \mathrm{MPa} \sqrt{\mathrm{m}}_{\mathrm{m}}\right.$.

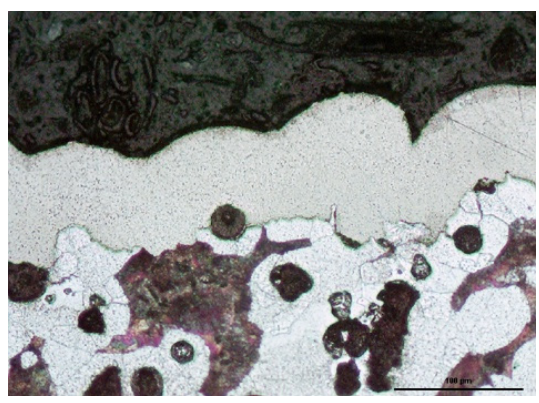

Figure 58: Ferritic-pearlitic DCI $(\mathrm{R}=0.5, \Delta \mathrm{K}=9 \mathrm{MPa} \sqrt{\mathrm{m}})$.

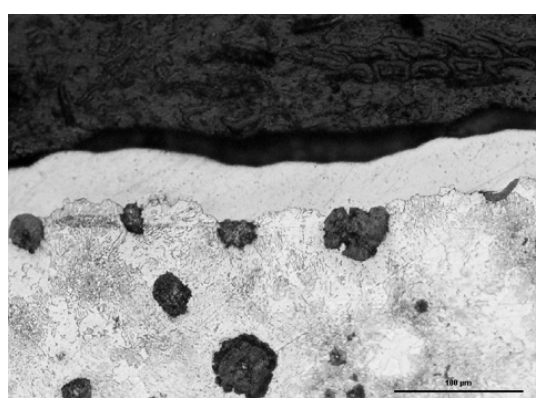

Figure 61: Ferritic-pearlitic DCI (annealed pearlitic DCI) $(\mathrm{R}=0.1, \Delta \mathrm{K}=10 \mathrm{MPa} \sqrt{\mathrm{m}})$.

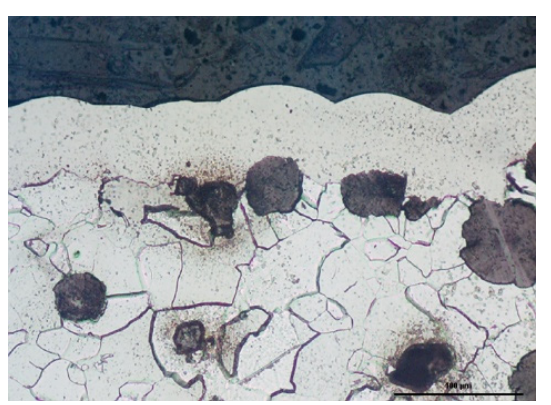

Figure 53: Ferritic DCI

$(\mathrm{R}=0.5, \Delta \mathrm{K}=15 \mathrm{MPa} \sqrt{\mathrm{m}}$.

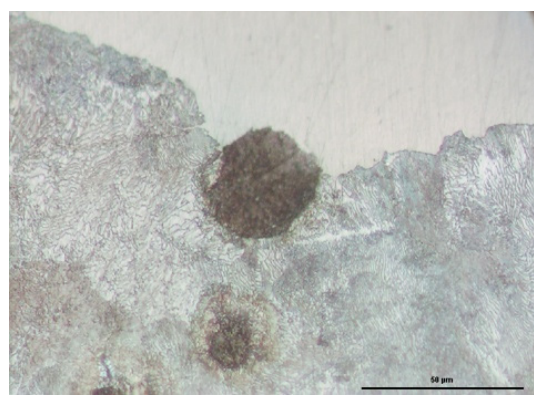

Figure 56: Pearlitic DCI

$(\mathrm{R}=0.1, \Delta \mathrm{K}=15 \mathrm{MPa} \sqrt{\mathrm{m}})$.

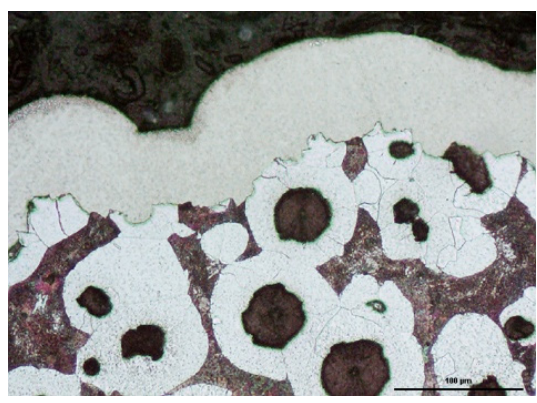

Figure 59: Ferritic-pearlitic DCI $(\mathrm{R}=0.1, \Delta \mathrm{K}=15 \mathrm{MPa} \sqrt{\mathrm{m}})$.

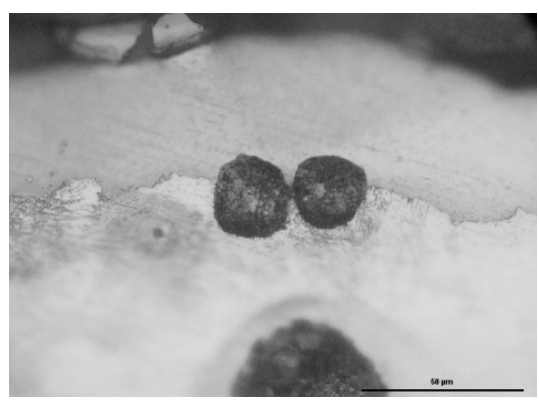

Figure 62: Ferritic-pearlitic DCI (annealed pearlitic DCI) $(\mathrm{R}=0.1, \Delta \mathrm{K}=15 \mathrm{MPa} \sqrt{\mathrm{m}})$.

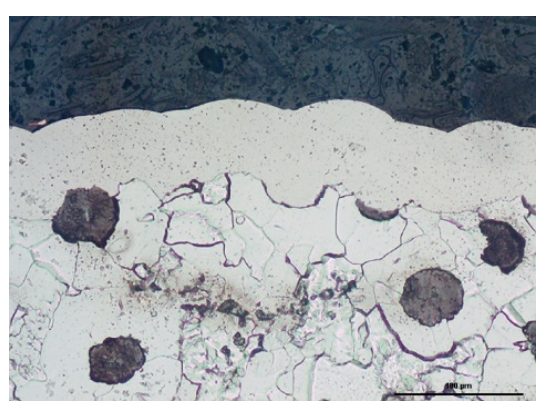

Figure 54: Ferritic DCI

$(\mathrm{R}=0.5, \Delta \mathrm{K}=10 \mathrm{MPa} \sqrt{\mathrm{m}})$.

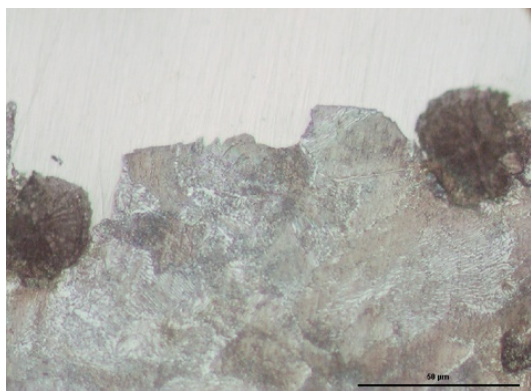

Figure 57: Pearlitic DCI

$(\mathrm{R}=0.1, \Delta \mathrm{K}=20 \mathrm{MPa} \sqrt{\mathrm{m}})$.

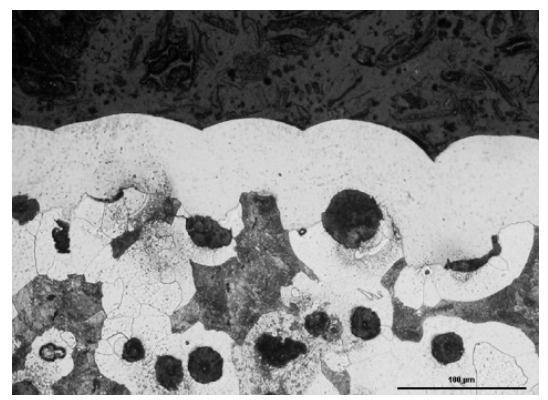

Figure 60: Ferritic-pearlitic DCI $(\mathrm{R}=0.1, \Delta \mathrm{K}=20 \mathrm{MPa} \sqrt{\mathrm{m}})$.

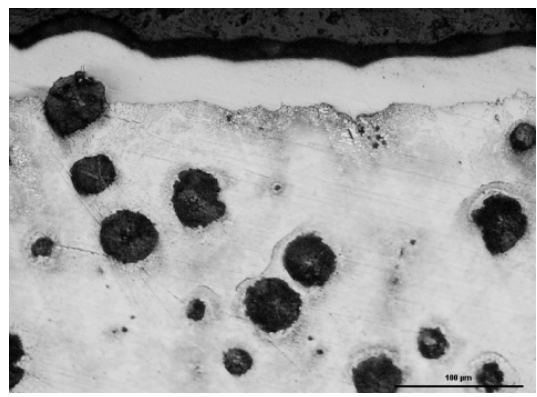

Figure 63: Ferritic-pearlitic DCI (annealed pearlitic DCI) $(\mathrm{R}=0.1, \Delta \mathrm{K}=20 \mathrm{MPa} \sqrt{\mathrm{m}})$.

Also austempered DCI crack profile is characterized by the presence of sound and partially disintegrated graphite nodules (Fig. 64, 65 and 66). Around graphite nodule is evident a ferritic shield: its morphology is quite different from GJS500-7 DCI, but it is always evident. 


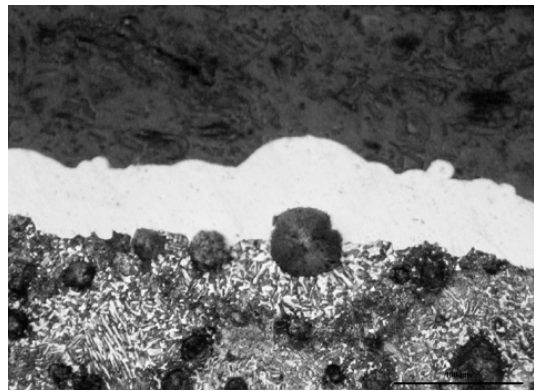

Figure 64: Austempered DCI $(\mathrm{R}=0.1, \Delta \mathrm{K}=15 \mathrm{MPa} \sqrt{\mathrm{m}})$.

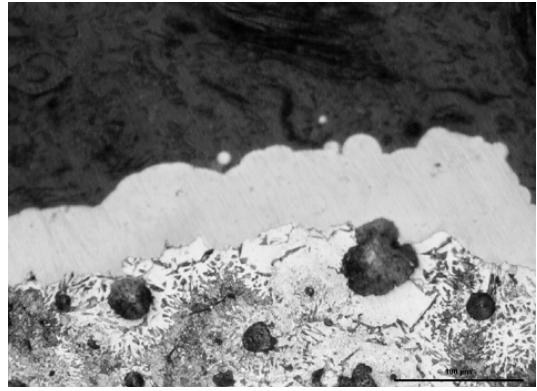

Figure 65: Austempered DCI $(\mathrm{R}=0.1, \Delta \mathrm{K}=9 \mathrm{MPa} \sqrt{\mathrm{m}})$.

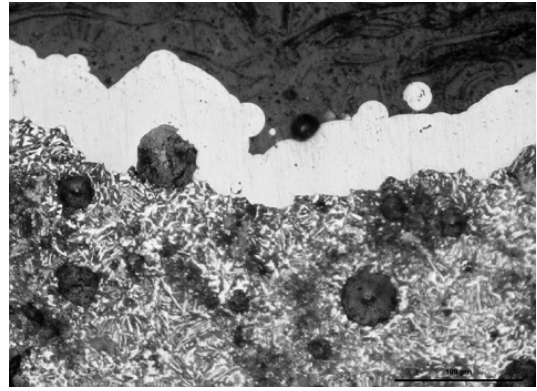

Figure 66: Austempered DCI $(\mathrm{R}=0.1, \Delta \mathrm{K}=20 \mathrm{MPa} \sqrt{\mathrm{m}})$.

\section{COMMENTS AND CONCLUSIONS}

1 ccording to the experimental results shown in this work, it is evident that it is necessary both a good graphite nodules morphology control and a microstructure optimization, in order to increase the DCI fatigue crack propagation resistance. Both phases volume fraction and phases morphology are important parameters, and microstructure importance is not only connected to its intrinsic fatigue crack propagation resistance, but also to the possible interactions with nodules. Graphite elements do not only act as "crack arresters", due to their peculiar shape: in fact, depending on matrix microstructure, they can also increase the DCI fatigue crack propagation resistance by means of an increase of the crack closure effect, with a consequent decrease of the $\Delta \mathrm{K}$ value that is effective at the crack tip.

For all the investigated DCI, graphite elements "ductile" or "fragile" debonding seems to be one of the main damaging micromechanism, with a respectively more or less evident plastic deformations of the matrix around the nodules. A model of the interaction between fatigue crack and graphite nodules during debonding, for different applied $\mathrm{K}$ values, is shown in Fig. 67.

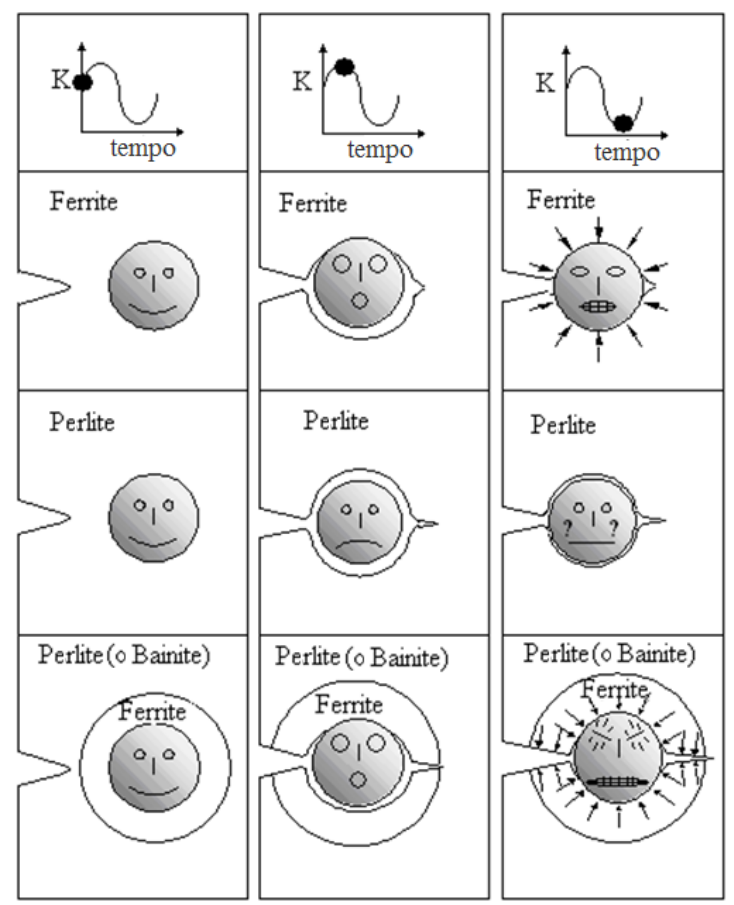

Figure 67: Microstructure influence on graphite nodules - matrix debonding.

Considering pearlitic DCI, fragile debonding implies a negligible matrix plastic deformation: as a consequence, graphite nodule merely play as "mechanical obstruction", mechanical reducing the crack closure corresponding to $\mathrm{K}_{\min }$. Ferritic 
DCI, implying an evident graphite nodules plastic debonding with an evident matrix plastic deformation. Corresponding to highe $\mathrm{K}$ values, a matrix plastic deformation is obtained and, corresponding to the lower $\mathrm{K}$ values, the "mechanical obstruction" is more important, implying a partial graphite nodule disgregation. Comparing the fatigue crack propagation resistance of the investigated pearlitic and ferritic DCI, the consequence is evident: higher $\mathrm{R}$ and $\Delta \mathrm{K}$ values implies an increase of the importance of the ductile debonding in ferritic DCI, with a consequent increase of the crack closure effect importance and, consequentely, obtaining lower crack growth rate values for the same loading conditions.

Ferritic-pearlitic GJS500-7 and austempered DCI are characterized by an analogous phases distribution, with a pearlitic or bainitic matrix, and ferrite grains as shields around graphite nodules (more evident for the GJS500-7). Considering that both pearlite and bainite are characterized by lower ductility values if compared to ferrite, it is possible to propose an additional crack closure effect mechanism. This mechanism is connected to the peculiar phases distribution and to their different mechanical behaviour. During fatigue loading, with $\mathrm{K}$ that ranges between $\mathrm{K}_{\max }$ and $\mathrm{K}_{\min }$, deformation level in the involved phases (ferrite and pearlite or bainite) is quite different:

- Corresponding to $K_{\max }$, due to the higher ferrite ductility, plastic deformation level in ferritic shields is higher than in pearlitic or bainitic matrix;

- Nearby $K_{\min }$ values, pearlitic (or bainitic) matrix induces a compression stress state on ferritic shields and, consequentely, on graphite nodules, with a consequent increase of crack closure effect importance. Both GJS5007 and austempered DCI show the higher fatigue crack propagation resistance, mainly corresponding to higher $\mathrm{R}$ and $\Delta \mathrm{K}$ values.

The proposed mechanism is connected both to the different mechanical behaviour of ferrite and pearlite (or bainite) and to the peculiar phases distribution. In fact, considering the ferritic-pearlitic DCI obtained by means of an annealing of a pearlitic DCI, ferrite is not localized as ferritic shields around graphite nodules. As a consequence, the additional crack closure mechanism could not be activated and fatigue behaviour of the ferritic-pearlitic DCI obtained by means of an annealing of a pearlitic DCI is analogous to the the behaviour of the pearlitic DCI (Fig. 13 and 14).

As conclusion, DCI fatigue crack propagation resistance is strongly affected both by graphite nodulization level and by microstructure, with the phases distribution that plays a key role especially for higher $\mathrm{R}$ or $\Delta \mathrm{K}$ values.

\section{REFERENCES}

[1] C. Labrecque, M. Gagne, Canadian Metallurgical Quarterly, 37 (1998) 343.

[2] R.G. Ward, An Introduction to the Physical Chemistry of Iron and Steel Making, Arnold, London (1962).

[3] K. Tokaji, T. Ogawa, K. Shamoto, Fatigue, 16 (1994) 344.

[4] K. Selby, Int. J. of Fatigue, 12 (1982) 124.

[5] F.D. Griswold Jr., R.I. Stephens, Int. J. of Fatigue 1 (1987) 3.

[6] K. Tokaji. T. Ogawa, K. Shamoto, Fatigue, 16 (1994) 344.

[7] G.L. Greno, J.L. Otegui, R.E. Boeri, Int. J. of Fatigue, 21 (1999) 35.

[8] J. Pokluda, J. Svejcar, In: Fatigue 99, Pechino (1999) 487.

[9] J. Zuidema, L. Wijnmaalen, C. van Eldijk in Fatigue 99, Pechino (1999) 2071.

[10] P. Hübner, H. Schlosser, G. Pusch, H. Biermann, Int. J. of Fatigue, 29 (2007) 1788.

[11] F. Iacoviello, W. Polini, La Metallurgia Italiana, 7-8 (2000) 31.

[12] F. Iacoviello, M. Cavallini, In: $28^{\circ}$ Convegno Nazionale AIM, Milano (2000) 1029.

[13] F. Iacoviello, M. Cavallini, La Metallurgia Italiana, 1 (2003) 31.

[14] F. Iacoviello, V. Di Cocco, In: International Conference on Fatigue Crack Paths, Parma (2003), 116

[15] F. Iacoviello, O. Di Bartolomeo, M. Cavallini, In: Convegno Nazionale AIM, Vicenza (2004), 19.

[16] M. Cavallini, O. Di Bartolomeo, F. Iacoviello, In: International Conference on Crack Paths (CP2006), Parma (2006) 13.

[17] M. Cavallini, A. De Santis, O. Di Bartolomeo, D. Iacoviello, F. Iacoviello, In: $31^{\circ}$ Convegno Nazionale AIM, Milano (2006) 31.

[18] V. Di Cocco, F. Iacoviello, F. Franzese, In: Convegno IGFXIX, Milano (2007) 7.

[19] M. Cavallini, O. Di Bartolomeo, F. Iacoviello, Engineering Fracture Mechanics, 75 (2008) 694.

[20] V. Di Cocco, F. Iacoviello, F. Franzese, In: XXXII Convegno Nazionale AIM, Ferrara (2008) 38.

[21] F. Iacoviello, V. Di Cocco, F. Franzese, In: Convegno IGFXX, Torino (2009).

[22] ASTM Standard test Method for Measurements of fatigue crack growth rates (E647-93), Annual Book of ASTM Standards (1993), 0301, American Society for Testing and Materials. 
[23] W. Elber (1971), ASTM STP 486, 280.

[24] R.O. Ritchie, S. Suresh (1982), Metall. Trans. A, 13A, 937. 